\title{
QUANTUM LEARNING DALAM PERSPEKTIF PENDIDIKAN ISLAM
}

\section{Ach Zayadi}

Sekolah Tinggi Agama Islam ALHIKMAH Jakarta

zayadi@psq.or.id

\section{Abstract}

The learning approach with the concept of quantum learning is a concept holding a strong philosophy that learning is a lifelong activity, which is implemented in a fun way at a class and presented with a methodology that is based on a curriculum as a blend of academic skills, physical achievements, and life skills. At a glance, this quantum approach is quite relevant to the lifelong educational philosophy that became the foundation of Islamic Education. The nature of education of Qur'an (Islam) is "rabbany" based on the first verse in the first revelation. People who carry out are also called "rabbany" who are described by alQuran with the characteristics include teaching the book of Allah, both written (Al Qur'an) and the unwritten (the universe), and study of it continuously. This literature review will reveal another perspective on the quantum approach in optical studies of Islam.

Keywords: Quantum Learning, Islamic education 


\section{Abstrak}

Pendekatan pembelajaran dengan konsep quantum learning adalah sebuah konsep yang memegang kuat falsafah bahwa belajar adalah kegiatan seumur hidup, diimplementasikan dalam kelas dengan cara yang menyenangkan, serta disajikan pula dengan metodologi yang didasarkan pada kurikulum yang merupakan perpaduan antara keterampilan akademis, prestasi fisik, dan keterampilan hidup (life skills). Sekilas pendekatan quantum ini sangatlah relevan dengan falsafah pendidikan sepanjang hayat yang menjadi pijakan dalam pendidikan Islam. Sifat pendidikan al-Qur'an (Islam) adalah "rabbany" berdasarkan ayat yang pertama dalam wahyu pertama. Orang yang melaksanakan juga disebut "rabbany" yang oleh al-Qur'an dijelaskan cirinya antara lain mengajarkan kitab Allah, baik yang tertulis (al-Qur'an) maupun yang tidak tertulis (alam raya) serta mempelajarinya secara terus menerus. Kajian literatur ini akan menguak persfektif lain tentang pendekatan quantum dalam optik kajian Islam.

Kata Kunci: Quantum Learning, Pendidikan Islam 


\section{A. PENDAHULUAN}

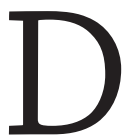

alam perspektif sejarah, pendidikan merupakan suatu gerakan yang telah berumur sangat tua. Dalam bentuk yang sederhana dapat dipahami bahwa pendidikan sudah dijalankan sejak dimulainya kehidupan manusia di muka bumi, ini berarti pendidikan berkembang serta berproses bersama-sema dengan proses perkembangan hidup dan kehidupan manusia itu sendiri. ${ }^{1}$ Oleh karenanya, pendidikan harus didesain mengikuti irama perubahan zaman yang menyertai manusia.

Manusia sebagai tema sentral dalam sebuah proses pendidikan dalam perkembangannya banyak dipengaruhi oleh pembawaan dan lingkungan ${ }^{2}$. Pembawaan yang dimaksud, yaitu berbagai macam potensi atau kemampuan dasar (fitrah) yang telah dibawa semenjak lahir. Dengan adanya berbagai macam kemampuan dasar tersebut, maka manusia dalam hidup dan kehidupannya tidak hanya berdasar pada insting atau naluri saja seperti binatang, tetapi juga berdasarkan dari berbagai potensi yang dimilikinya. ${ }^{3}$

Untuk mengembangkan potensi atau kemampuan dasarnya tersebut, manusia membutuhkan adanya bantuan dari orang lain untuk membimbing, mendorong dan mengarahkan agar berbagai potensi tersebut dapat bertumbuh dan berkembang secara wajar dan optimal, sehingga kelak hidupnya dapat berdaya guna dan berhasil guna. Dengan begitu mereka akan dapat memenuhi kebutuhan hidupnya dan dapat menyesuaikan diri dengan lingkungannya. ${ }^{4}$

Dalam dunia pendidikan, dikenal sebuah pendekatan pembelajaran yang diberi nama quantum learning, yang berupaya memanfaatkan secara optimal potensi atau kemampuan dasar yang dimiliki oleh manusia. Pemanfaatan potensi yang dimiliki manusia tersebut dilakukan dengan berbagai macam cara atau tehnik yang melibatkan keseluruhan kepribadian baik intelek, fisik maupun emosi.

1 Zuhairini, dkk., Filsafat Pendidikan Islam, (Jakarta: Bumi Aksara, 1995), h. 92.

2 Ahmad Tafsir, Ilmu Pendidikan Dalam Perspektif Islam, (Bandung: Rosdakarya, 1994), h. 34.

3 Zuhairini, dkk., Filsafat Pendidikan Islam, h. 94.

4 Zuhairini, Filsafat Pendidikan Islam, h. 94. 
Quantum learning berangkat dari falsafah dasar (natural) yang mendasari semua kurikulum yang ada di sana. ${ }^{5}$ Filsafat dasar yang dimaksud yaitu falsafah eksistensi manusia yang secara natural memiliki potensi yang bisa dikembangkan. Manusia ketika dilahirkan bukanlah dalam keadaan kosong, tidak membawa apaapa, tetapi justru berisi dengan daya-daya perbuatan.

Di sini dapat terlihat bahwa quantum learning menolak pendapat kaum empirisme dalam aliran pendidikan yang dimotori oleh John Locke dengan teori tabularasanya yang menyatakan bahwa seorang anak ketika dilahirkan jiwanya dalam keadaan kosong, laksana kertas putih atau tabularasa yang belum ada tulisan di atasnya. ${ }^{6}$

Untuk mendukung falsafah dasar ini, maka dalam quantum learning dipersiapkanlah lingkungan yang mendukung. Sehingga semua siswa merasa penting, aman dan nyaman. Ini dimulai dengan lingkungan fisik sebenarnya, yang diperindah dengan tanaman, seni dan musik. Lingkungan emosional juga mendapat perhatian yang tidak kalah pentingnya. Para pembimbing dalam quantum learning adalah pakar yang membentuk jalinan pengertian. ${ }^{7}$

Dari sini quantum learning juga jelas terlihat tidak sejalan dengan pemikiran kaum nativisme yang dipelopori oleh Arthur Schopenhauer dengan teori bakatnya yang menyatakan bahwa bakat itu adalah segalanya dan posisi guru sebagai pendidik hanya berperan sebagai unsur fasilitator dalam sebuah sistem pendidikan. ${ }^{8}$

Dari sudut pandang filsafat, nampak bahwa quantum learning mengikuti teori konvergensi yang mengkombinasikan faktor endogen (bakat yang dibawa sejak lahir, nativisme) dengan faktor eksogen (pengaruh-pengaruh luar, empirisme) sebagai dua faktor yang berjalan bersamaan dalam pembentukan masa depan

5 Bobby de Porter \& Mike Hernacki, Quantun Learning: Membiasakan Belajar Nyaman dan Menyenangkan, (Bandung: Kaifa, 1999), h. 8.

6 Ahmad Tafsir, Filsafat Umum : Akal dan Hati Sejak Thales Sampai James, (Bandun: Remaja Rosdakarya, 1992), h. 136.

7 Bobby de Porter, dkk., Quantun Learning, h. 8.

8 Mastuhu, Memberdayakan Sistem Pendidikan Islam, (Jakarta: Logos, 1999), h. 26. 
anak didik..$^{9}$ Menurut Islam, konvergensi inilah yang mendekati kebenaran. Salah satu sabda Rasulullah Saw:

كل مولود يولد على الفطرة فابواه يهودانه اوينصرانه او يمجيسانه (رواه البخاري

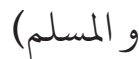

"Tiap orang dilahirkan membawa fitrah, ayah ibunyalah yang menjadikannya Yahudi, Nasrani, atau Majusi (HR. Bukhari dan Muslim)". ${ }^{10}$

Hadits Nabi di atas menekankan, bahwa fitrah yang dibawa semenjak lahir bagi anak itu sangat besar dipengaruhi oleh lingkungan. Fitrah itu sendiri tidak akan berkembang tanpa dipengaruhi kondisi lingkungan sekitar. Faktor-faktor eksternal bergabung dengan fitrah, sifat dasarnya bergantung kepada sejauh mana interaksi eksternal dengan fitrah itu berperan. ${ }^{11}$

Karena itu, salah satu prinsip sistem pendidikan Islam adalah keharusan untuk menggunakan metode pendekatan yang menyeluruh terhadap manusia, meliputi dimensi jasmani, rohani dan semua aspek kehidupan, baik yang dapat dijangkau dengan akal maupun yang hanya diimani melalui kalbu, bukan hanya lahiriah saja, tetapi juga batiniahnya. ${ }^{12}$ Dan metode pendekatan yang holistik (menyeluruh) tersebut salah satunya telah diterapkan dalam quantum learning.

Berdasarkan asumsi awal di atas, tulisan ini berusaha mengelaborasi lebih jauh metode pendekatan quantum learning tersebut, terutama pandangan-pandangannya tentang manusia, lingkungan (belajar), dan metodologi yang digunakan dalam proses pembelajaran, untuk kemudian melihatnya dari perspektif pendidikan Islam.

9 Mastuhu, Memberdayakan, h. 27.

10 Imam Abi Abdillah Muhammad bin Ismail, Shahih Bukhari, Juz I, (Tt.: Daral-Fikr, T.t), h. 118.

11 Abdurrahman Saleh Abdullah, Teori-teori Pendidikan Berdasarkan Al-Qur'an (Jakarta: Rineka Cipta, 1990), h. 62.

12 Mummad Qutub, Sistem Pendidikan Islam, Alih Bahasa Salman Harun (Bandung: Al-Ma'ruf, 1984), h. 27-28. 


\section{B. QUANTUM LEARNING DALAM PERSFEKTIF PENDIDIKAN ISLAM}

Pendidikan Islam adalah suatu bangunan yang sangat menarik, apabila dibandingkan dengan quantum learning yang hanyalah suatu metode atau pendekatan dalam dunia pendidikan, maka kelihatan tidak seimbang. Namun berangkat dari kesuksesan quantum learning sebagai sebuah pendekatan dalam dunia pendidikan, tidak keliru kiranya apabila dilakukan kajian yang mendalam terhadapnya dan melihatnya dari perspektif pendidikan Islam.

Ada tiga konsep kunci dari quantum learning yang hendak dilihat dari sudut pandang pendidikan Islam. Yang pertama, pandangannya tentang manusia; kedua pandangannya tentang lingkungan yang mendukung proses pembelajaran dan yang ketiga metodologi pengajaran yang diterapkan di sana. Lebih lanjutnya akan dipaparkan berikut ini :

a) Pandangan Tentang Manusia

Manusia sebagaimana diketahui sangat menentukan dalam proses pendidikan. Pembicaraan apapun mengenai pendidikan pastilah mengupas manusia lebih dahulu.

Quantum learning sebagai sebuah pendekatan dalam dunia pendidikan, tidak lepas dari ini juga. Setiap manusia menurut quantum learning mempunyai potensi yang sama. Dan perbedaan yang ada lebih pada bagaimana manusia itu memanfaatkan otaknya. Pemikiran bahwa setiap orang mempunyai potensi yang sama, berdampak positif terhadap perkembangan anak didik. Setiap orang kemudian menyadari bahwa ia mempunyai peluang yang luar biasa besarnya. Pemahaman yang seperti ini, memungkinkan seseorang untuk meniru orang lain dan menggunakan orang itu sebagai model dengan mengatur pola berpikir dan tubuh yang seperti dia.

Dalam quantum learning, seluruh pribadi adalah penting, baik akal, fisik maupun emosi/pribadi. Kehormatan diri yang tinggi adalah material penting dalam membentuk pelajar yang 
sehat dan bahagia.

Dilihat dari perspektif pendidikan Islam, pandangan bahwa manusia mempunya potensi yang bisa dikembangkan sangatlah relevan. Bahkan ia merupakan salah satu pokok dari pemikiran pendidikan Islam. Manusia, sebagaimana yang diungkapkan oleh Quraish Shihab adalah makhluk yang selain diciptakan dari tanah (jasmani) dan ruh illahi (akal dan ruhani), ia diberi pula anugerah berupa potensi, yang dengannya ia kemudian menjadi makhluk yang berkemampuan untuk menyusun konsep-konsep, mencipta, mengembangkan dan mengemukakan gagasan serta melaksanakannya. Potensi ini menurutnya adalah bukti yang membungkamkan malaikat yang tadinya merasa wajar untuk dijadikan khalifah di bumi, dan karenanya mereka bersedia sujud kepada Adam. ${ }^{13}$

Kata yang sepadan dengan potensi ini dalam konsep Islam adalah fitrah, yang mana bahwa fitrah manusia adalah kejadiannya sejak semula atau bawaan sejak lahir.

Pendidikan Islam sebagaimana pula yang telah diterapkan dalam quantum learning, berupaya untuk menampakkan secara maksimal potensi yang dimiliki oleh manusia itu. Dalam konferensi Internasional pertama tahun 1977 telah merumuskan tujuan pendidikan Islam sebagai "Sebuah upaya untuk mencapai pertumbuhan kepribadian manusia yang menyeluruh secara seimbang. Tujuan yang telah dirumuskan dalam konferensi tersebut, juga disepakati oleh banyak pakar pendidikan Islam. Misalnya : Ali Ashraf menyatakan bahwa pendidikan seharusnya bertujuan menimbulkan pertumbuhan yang seimbang dari kepribadian total manusia. ${ }^{14}$

Pendidikan harus merealisasikan cita-cita (idealitas) Islam yang mencakup pengembangan kepribadian muslim yang bersifat menyeluruh secara harmonis yang berdasarkan psikologis dan fisiologis maupun yang mengacu pada keimanan

13 M. Quraish Shihab, Wawasan al-Qur'an : Tafsir Maudhu'i Atas Pelbagai Persoalan Umat, (Bandung: Mizan, 1996), h. 283.

14 Ali Ashraf, Horison Baru Pendidikan Islam, (Jakarta: Pustaka Firdaus, 1993), h. 2. 
dan sekaligus berilmu pengetahuan secara berkesinambungan sehingga terbentuklah manusia muslim yang sempurna yang berjiwa tawakal secara total kepada Allah. Dalam hal tersebut, pendidikan merupakan upaya untuk mengembangkan bakat dan kemampuan individual, sehingga potensi-potensi kejiwaan itu dapat diaktualisasikan secara sempurna. Potensi-potensi itu sesungguhnya merupakan kekayaan dalam diri manusia yang amat berharga.

Dalam konsep Islam, dengan terbinanya seluruh potensi manusia secara sempurna diharapkan ia dapat melaksanakan fungsi pengabdiannya sebagai khalifah di muka bumi. Atas dasar pemahaman ini, tujuan pendidikan al-Qur'an (Islam) adalah membina manusia secara pribadi dan kelompok sehingga mampu menjalankan fungsinya sebagai hamba dan khalifahNya guna membangun dunia ini sesuai dengan konsep yang ditetapkan Allah. Atau dengan kata lain yang lebih singkat dan sering digunakan oleh al-Qur'an untuk bertakwa kepada-Nya. Takwa itu sendiri menurut Fazlur Rahman adalah tingkatan tertinggi yang menunjukkan kepribadian manusia yang benarbenar utuh dan integral, inilah semacam stabilitas yang terjadi setelah semua unsur sifat-sifat positif diserap masuk ke dalam diri manusia.

Apabila dalam quantum learning, semua kurikulum yang ada merupakan kombinasi dari tiga unsur; keterampilan akademis, prestasi fisik, dan keterampilan hidup, serta seluruh pribadi manusia dianggap penting, baik akal, fisik, maupun emosi/pribadi, maka dalam Islam hal tersebut juga dikembangkan dengan penelitian yang cukup serius, bahkan lebih dari sekedar itu. Dalam perspektif Islam manusia yang dibina adalah makhluk yang memiliki unsur-unsur material (jasmani) dan immaterial (akal dan jasmani). Pembinaan akalnya menghasilkan ilmu, pembinaan jiwanya menghasilkan kesuksesan/etika, sedangkan pembinaan jasmaninya menghasilkan keterampilan.

Islam tidak hanya menonjol dalam memperhatikan semua 
segi eksistensi manusia dan tidak mengabaikan sedikitpun berbagai macam daya yang terdapat di dalamnya. Tetapi yang paling menonjol adalah bahwa Islam sejalan dengan fitrah dan hal-hal yang lebih jauh dari itu. Eksistensi manusia yang dimaksud di sini adalah jasmani maupun rohani atau jasmani, akal dan rohani. Apabila akal dianggap sebagai unsur yang berdiri sendiri di luar jasmani dan rohani itu. Antara yang satu dengan yang lain tidak dapat dipisahkan. Manusia tidak hanya terdiri dari jasmani yang berdiri sendiri tanpa hubungan akal dan roh. Manusia bukan hanya akal yang berdiri sendiri, tidak ada kaitannya dengan tubuh dan roh dan bukan pula hanya roh tanpa ada kaitannya dengan akal dan tubuh. Manusia adalah wujud yang utuh dari unsur-unsur yang tali temali.

Berangkat dari penjelasan di atas, nampak bahwa pandangan dalam quantum learning tentang manusia, apabila dilihat dari perspektif pendidikan Islam yang sangat komprehensif, mencakup di dalamnya aspek jasmani dan rohani serta akal. Sedang dalam quantum learning manusia lebih dilihat dari sudut pandang fisik dan emosional (psikologis) yang mendukung dalam proses pembelajaran. Potensi yang merupakan pembawaan alamiah manusia dalam quantum learning, pada esensinya lebih pada hal yang bersifat fisiologis, dalam artian kemampuan manusia untuk berkembang setiap orang adalah sama besarnya. Sedikit berbeda dengan potensi atau fitrah dalam pendidikan Islam, yang didalamnya juga termasuk potensi untuk beragama.

b) Pandangan Tentang Lingkungan

Dalam konsep quantum learning, semua kurikulum secara harmonis merupakan kombinasi dari tiga unsur: Keterampikan akademis, prestasi fisik dan keterampilan dalam hidup. Yang mendasari kurikulum ini adalah filsafat dasar dengan keyakinan bahwa dalam belajar agar efektif. Ia harus dapat dan menyenangkan. Belajar dalam konsep quantum learning 
adalah kegiatan seumur hidup yang dapat dilakukan dengan menyenangkan dan berhasil.

Untuk mendukung falsafah ini, dalam quantum learning kemudian dipersiapkan lingkungan yang bisa menjadikan semua siswa merasa penting, aman dan nyaman. Ini dimulai dengan lingkungan fisik yang diperindah dengan tanaman, seni dan musik. Ruangan juga dibentuk sedemikian rupa, agar terasa pas untuk kegiatan belajar seoptimal mungkin. Lingkungan emosional juga mendapat perhatian yang tak kurang seriusnya. Para pembimbing dalam quantum learning adalah para pakar yang membentuk jalinan pengertian, dan setelah mereka memantapkan daerah aman secara emosional, mereka menghadapkan para siswa pata tantangan-tantangan dimana mereka memperoleh kesuksesan waktu demi waktu.

Dalam pespektif pendidikan Islam, lingkungan sangatlah berpengaruh terhadap potensi (pembawaan yang dimiliki oleh seorang anak didik). Untuk mengembangkan potensi/ kemampuan dasarnya, manusia membutuhkan adanya bantuan dari orang lain untuk membimbing, mendorong, mengarahkan agar berbagai potensi tersebut dapat tumbuh dan berkembang secara wajar dan optimal, sehingga kelak hidupnya, dapat berdaya guna dan berhasil guna. Sesuai dengan hadits Rasulullah SAW. Dinyatakan bahwa tiap orang itu dilahirkan dalam keadaan fitrah, ayah dan ibunyalah yang menjadikannya Yahudi, Nasrani, atau Majusi. Ayah dan Ibu dalam hadits ini adalah lingkungan sebagaimana yang dimaksudkan oleh para ahli pendidikan. Kedua-duanya itulah, menurut hadits ini yang menentukan perkembangan seseorang.

Dalam arti yang luas lingkungan mencakup iklim dan geografis, tempat tinggal, adat istiadat, pengetahuan, pendidikan dan alam. Dengan kata lain, lingkungan ialah segala sesuatu yang tampak dan terdapat dalam alam kehidupan yang senantiasa berkembang. Ia adalah seluruh yang ada, baik manusia maupun benda buatan manusia. 
Perbedaan yang cukup signifikan antara quantum learning dengan pendidikan Islam dalam memandang lingkungan, terletak pada pemaknaan dari lingkungan itu sendiri. Dalam quantum learning, lingkungan yang dimaksud sebagaimana yang diungkapkan oleh Bobbi De Porter, adalah lingkungan yang mendukung proses belajar, yang didalamnya tercakup lingkungan fisik dan emosional. Jadi, ia lebih bersifat mikro (sempit) dan terbatas, berlainan dengan pendidikan Islam yang melihat lingkungan yang mendukung perkembangan potensi manusia secara makro. Namun secara filosofis dalam perspektif pendidikan Islam, pandangan quantum learning tersebut adalah sama, bahwa untuk pengembangan potensi manusia secara optimal perlu dukungan dari lingkungan sekitar.

c) Metodologi Penelitian

Dalam quantum learning ada falsafah yang dipegang kuat, bahwa belajar adalah kegiatan seumur hidup yang dapat dilakukan dengan menyenangkan dan berhasil. Kurikulum yang diterapkan di sana, merupakan responden antara keterampilan akademis, prestasi fisik, dan keterampilan dalam hidup dengan pengoptimalan pada akal, fisik, dan emosi/pribadi.

Quantum learning pada dasarnya berakar dari upaya Dr. BiorgiLozanov, yangbereksperimen denganapayang disebutnya sebagai suggestologi atau suggestopedia. Pada prinsipinya Lozanov dengan suggestologi mengajukan pemikiran bahwa setiap detil itu berarti. Sugesti pasti dan dapat mempengaruhi hasil situasi belajar baik sugesti positif ataupun negatif. Beberapa teknik yang digunakannya untuk memberikan sugesti positif adalah mendudukkan murid secara nyaman, memasang musik latar di dalam kelas, meningkatkan partisipasi individu, menggunakan poster-poster untuk memberi kesan besar sambil menonjolkan informasi dan menyediakan guru-guru yang terlatih baik dalam seni pengajaran sugestif.

Selain dengan suggestology, quantum learning juga mendasarkan dirinya pada accelerated learning (belajar 
ekselerasi). Pada intinya ia didefinisikan sebagai memungkinan siswa untuk belajar dengan kecepatan yang mengesankan, dengan upaya yang normal, dibarengi dengan kegembiraan. Metode yang diterapkan dalam belajar akselerasi ini, menyatukan unsur-unsuryang sekilas tampak tidakmempunyai persamaan ; hiburan, permainan, warna, cara berfikir positif, kebugaran fisik, dan kesehatan emosional, dan semua unsur ini bekerja sama untuk menghasilkan pengalaman belajar yang efektif.

Quantum learning juga mencakup aspek-aspek penting dalam program neurolingustik (NLP) yaitu suatu penelitian tentang bagaimana otak mengatur informasi. Program ini meneliti hubungan antara bahasa dan perilaku dan dapat digunakan untuk menciptakan jalinan pengertian antara siswa dan guru. Para pendidik dengan pengetahuan NLP mengetahui bagaimana menggunakan bahasa yang positif untuk meningkatkan tindakan-tindakan positif, yang merupakan faktor penting untuk merangsang fungsi otak paling efektif. Kurikulum yang diterapkan dalam quantum learning merupakan perpaduan antara keterampilan akademis, prestasi fisik, dan keterampilan dalam hidup dengan pengoptimalan pada akal, fisik dan emosional/pribadi, dalam implementasinya di lapangan, metode yang diterapkan untuk mencapai semua itu, yaitu dengan menciptakan lingkungan yang mendukung, baik fisik, maupun emosi.

Pada lingkungan fisik, ini dilakukan dengan membangun suatu kondisi yang positif, aman dan mendukung, santai, penjelajahan (esploratory) dan menggembirakan. Dalam suasana yang nyaman, cukup penerangan, enak dipandang dan ada musiknya. Sedang pada lingkungan emosional, yang dibangun adalah suatu jalinan pengertian, baik antara pembimbing (guru) dengan siswanya, maupun antara sesama anak didik. Dalam quantum learning, para pembimbing adalah para pakar yang membentuk jalinan pengertian, dan setelah mereka memantapkan daerah aman secara emosional, mereka 
menghadapkan para siswa pada tantangan-tantangan dimana mereka memperoleh kesuksesan dari waktu demi waktu. Di lingkungan yang aman ini, dimana telah tercipta jalinan pengertian, baik antara pembimbing dengan siswa maupun antara sesama siswa, anak didik umumnya membuka diri untuk memperluas wilayah kenyamanan mereka dan mencoba hal-hal baru, dan itulah keadaan fikiran yang ideal untuk belajar secara optimal. Dalam quantum learning, hanya setelah untuk menghasilkan keaadaan pikiran yang seperti inilah baru diperkenalkan keterampilan akademis yang membantu para anak didik menjadi lebih baik di sekolah.

Dalam melakukan terobosan-terobosan belajar, quantum learning melakukan beberapa pergeseran paradigma pola pikir "tidak mampu" dengan memberikan tantangan-tantangan fisik yang digunakan sebagai simbol-simbol untuk terobosanterobosan belajar.

Dalam perspektif pendidikan Islam, konsep quantum learning yang memegang kuat falsafah bahwa belajar adalah kegiatan seumur hidup yang dapat dilakukan dengan menyenangkan dan berhasil dengan metodologi yang didasarkan pada kurikulum yang merupakan perpaduan antara keterampilan akademis, prestasi fisik, dan keterampilan dalam hidup, sangatlah relevan dengan falsafah pendidikan sepanjang hayat yang menjadi pijakan dalam pendidikan Islam.

Sifat pendidikan al-Qur'an (Islam) adalah "rabbany" berdasarkan ayat yang pertama dalam wahyu pertama. Orang yang melaksanakan juga disebut "rabbany" yang oleh al-Qur'an dijelaskan cirinya antara lain mengajarkan kitab Allah, baik yang tertulis (al-Qur'an) maupun yang tidak tertulis (alam raya) serta mempelajarinya secara terus menerus. ${ }^{15}$

Jangkauan yang harus dipelajari, yang demikian luas dan menyeluruh itu, tidak dapat diraih secara sempurna oleh seseorang. Namun ia harus berusaha semaksimal mungkin

15 M. Quraish Shihab, Membumikan al-Qur'an: Fungsi Wahyu Dalam Kehidupan Masyarakat, (Bandung: Mizan. 1995), h. 177. 
untuk mendapatkan apa yang mampu diraihnya. Karenanya ia dutuntut untuk terus menerus belajar. Atas dasar ini, metodologi Islam dalam melakukan pendidikan adalah dengan melakukan pendekatan yang menyeluruh terhadap wujud manusia, sehingga tidak ada yang tinggal dan terabaikan sedikitpun, baik segi jasmani maupun segi rohani, baik segi kehidupannya secara psikis maupun kehidupannya secara mental.

Dalam sejarah pendidikan Islam dapat diketahui bahwa para pendidik muslim dalam berbagai situasi dan kondisi yang bebeda, telah menerapkan dan merumuskan berbagai macam metode pendidikan dan pengajaran. Metode pendidikan yang harus dipergunakan oleh para pendidik atau pengajar adalah yang berprinsip pada "Child centered" yang lebih mementingkan anak didik dari pada pendidik sendiri. Bagi Ibn Khaldun metode pendekatan dalam pendidikan anak adalah yang bersifat psikologis. Prinsip-prinsip yang disarankan adalah ; (1) tidak memberi pelajaran yang sulit kepada para pemula, dan anak didik harus diberi persiapan secara bertahap yang menuju kesempurnaannya, (2) Memberi pelajaran yang sesuai dengan daya tangkap anak didik, (3) jangan memberi ilmu yang melebihi kemampuan akal anak didik. ${ }^{16}$

Pendidikan jasmani (fisik) juga terdapat dalam konsep pendidikan Islam yang ditujukan untuk mempersiapkan diri manusia sebagai pengembang tugas khalifah di bumi, dan ini dilakukan melalui lataihan-latihan fisik. Mengenai permainan bagi Al-Ghazali tidak ada halangan memperbolehkan anak setelah keluar dari sekolahnya untuk bermain-main yang baik dengan cara bermainnya yang sopan, serta alat yang dipergunakan sesuai dengan usianya. Hal ini menurutnya, dimaksudkan agar anak itu dapat beristirahat secukupnya dari kelelahan belajar di sekolah dan supaya terhibur hatinya sesudah pelajaran-pelajaran dan memutar otak. ${ }^{17}$

16 H. M. Arifin, Filsafat Pendidikan Islam, (Jakarta: Bumi Aksara, 1993), h. 106.

17 Zainuddin, dkk., Seluk Beluk Pendidikan dari Al-Ghazali, (Jakarta: Bumi Aksara. 1991) h. 129. 
Pandangan bahwa fisik (jasmani) itu penting, kiranya tidak ada perbedaan antara pendidikan Islam dengan quantum learning. Hanya saja fisik (jasmani) yang dimaksudkan dalam quantum learning adalah fisik, dalam artian yang mendukung dalam proses pembelajaran, hal ini tidak lepas dari kenyataan bahwa quantum learning adalah suatu pendekatan dalam dunia pendidikan, yang tak punya basis ideologis sebagaimana halnya pendidikan Islam. Kajian-kajiannya yang mendalam secara fisiologis dan psikologis terhadap manusia, kiranya bisa menjadi masukan yang memperkaya khazanah pendidikan Islam untuk lebih "membumi” lagi.

Dalam hal metodologi pembelajaran, pendekatan psikologis dalam suasana yang hangat dan familiar dalam quantum learning secara esensial sangat relevan dengan ajaran Islam yang menginginkan kelembutan (soft approach) dalam proses pembelajaran. Namun kiranya berkaitan dengan metodologi pembelajaran. Pendidikan Islam hanya mempunyai konsep yang kurang begitu teruji di lapangan. Dalam artian ia hanya lebih pada dataran normatif, yang belum dielaborasi secara pragmatis dan empiris di lapangan.

Metode-metode pembelajaran yang telah dirumuskan dalam al-Qur'an seperti : metode iswar, metode teladan, metode targhib dan tarhib, terlepas dari substansi yang dibahas, merupakan metode-metode yang memandang sudah lazim dipergunakan dalam hampir setiap interaksi pembelajaran. Kiranya terobosan-terobosan dalam quantum learning yang menerapkan metode dengan global learning, menggunakan musik yang mendukung proses pembelajaran, perhatian yang intens terhadap emosi (kejiwaan) anak didik dan hal-hal lain dari metodologi pembelajaran yang diterapkan di sana, merupakan masukan yang sangat berguna bagi pendidikan Islam. 


\section{KESIMPULAN}

Tulisan ini bermuara pada kesimpulan akhir mengenai metode quantum dalam pembelajaran yang dilihat dalam optik pendidikan Islam sebagai berikut:

1. Dalam konsepsi learning, semua manusia (anak didik) dianggap memiliki potensi yang sama besarnya untuk bisa berkembang. Pengoptimalan potensi manusia ini dilakukan dengan pengaturan ungkapan belajar yang mendukung, baik lingkungan fisik maupun emosional. Metodologi pengajaran yang diterapkan adalah menyentuh semua sisi penting pribadi manusia, baik secara akal, fisik dan emosi (pribadi), dengan prinsip bahwa belajar adalah kegiatan seumur hidup yang menyenangkan dan berhasil.

2. Secara prinsipil konsepsi quantum learning tentang manusia (anak didik), lingkungan belajar dan metodologi pembelajaran banyak sesuai dengan yang terdapat dalam pendidikan Islam, pandangan quantum learning yang menyeluruh (holistik) terhadap manusia, yaitu pada akal, fisik dan jiwa (emosi) yang ditujukan pada upaya pengoptimalan potensi manusia dalam proses pembelajaran, secara prinsip sesuai dengan konsep pendidikan Islam yang melihat manusia secara integral dan holistik, meliputi seluruh aspek, baik jasmani maupun rohani, baik dunia maupuan akhirat. Perbedaannya bahwa potensi yang dimaksud dalam pendidikan Islam adalah fitrah (pembawaan) yang lebih diarahkan pada potensi untuk "beragama", sedang dalam quantum learning ia lebih dimaknai sebagai kemampuan dasar manusia untuk berkembang dengan melihat pada aspek fisiologisnya saja. Konsepsi ungkapan dalam quantum learning yang mendukung proses pembelajaran, dilihat dari perspektif pendidikan Islam secara maknawi tidak berbeda, bahwa lingkungan sangat berpengaruh dalam pengembangan kemampuan seorang anak didik. Hanya saja, dalam quantum learning, lingkungan yang dimaksudmerupakan "rekayasa” yang secara praktis diimplementasikan dalam bentuk penciptaan lingkungan yang kondusif terhadap proses pembelajaran, baik 
secara fisik maupun emosional. Adapun mengenai metodologi pembelajaran yang diterapkan dalam quantum learning secara konseptual tidak berbeda dengan metodologi pendidikan Islam, keduanya melakukan pendekatan secara psikologis, menyentuh sisi emosional peserta didik dengan membangkitkan semangat (motivasi) mereka untuk belajar sepanjang hayat dan dengan suasana yang menyenangkan. Hanya saja dalam quantum learning, metodologi pembelajaran yang diterapkan telah bersifat praktis dan empiris.[] 


\section{DAFTAR PUSTAKA}

Abdullah, Abdurrahman Saleh, Teori-teori Pendidikan Berdasarkan Al-Qur'an, Jakarta: Rineka Cipta, 1990.

Arifin, H. M., Filsafat Pendidikan Islam, Jakarta: Bumi Aksara, 1993.

Ashraf, Ali, Horison Baru Pendidikan Islam, Jakarta: Pustaka Firdaus, 1993.

Mastuhu, Memberdayakan Sistem Pendidikan Islam, Jakarta: Logos, 1999.

Muhammad, Imam Abi Abdillah bin Ismail, Shahih Bukhari, Juz I, Tt.: Daral-Fikr, tt.

Porter, Bobby de \& Mike Hernacki, Quantun Learning: Membiasakan Belajar Nyaman dan Menyenangkan, Bandung: Kaifa, 1999.

Qutub, Muhammad, Sistem Pendidikan Islam, Ter. Salman Harun, Bandung: Al-Ma'ruf, 1984.

Shihab, M. Quraish, Membumikan al-Qur'an: Fungsi Wahyu Dalam Kehidupan Masyarakat, Bandung: Mizan. 1995.

—, Wawasan al-Qur'an: Tafsir Maudhu'i atas Pelbagai Persoalan Umat, Bandung: Mizan, 1996.

Tafsir, Ahmad, Filsafat Umum: Akal dan Hati Sejak Thales Sampai James, Bandung, Remaja Rosdakarya, 1992.

, Ilmu Pendidikan Dalam Perspektif Islam, Bandung: Rosdakarya, 1994.

Zainuddin, dkk. Seluk Beluk Pendidikan dari Al-Ghazali, Jakarta: Bumi Aksara, 1991. 